\title{
GATA-4 is a granulosa cell factor employed in inhibin-a activation by the TGF- $\beta$ pathway
}

\author{
M Anttonen ${ }^{1,2 \star}$, H Parviainen ${ }^{1,2 *}$, A Kyrönlahti ${ }^{1,2}$, M Bielinska ${ }^{3}$, D B Wilson ${ }^{3,4}$, O Ritvos ${ }^{1,5}$ \\ and M Heikinheimo',2,3 \\ ${ }^{1}$ Program for Developmental and Reproductive Biology, Biomedicum Helsinki, ${ }^{2}$ Children's Hospital and Haartman Institute, University of Helsinki, 00014 Helsinki, Finland \\ Departments of ${ }^{3}$ Pediatrics and ${ }^{4}$ Molecular Biology and Pharmacology, Washington University School of Medicine, St Louis Children's Hospital, St Louis, Missouri 63110, USA \\ ${ }^{5}$ Department of Bacteriology and Immunology, Haartman Institute, University of Helsinki, 00014 Helsinki, Finland
}

(Requests for offprints should be addressed to M Heikinheimo at first address; Email: markku.heikinheimo@ helsinki.fi)

*(M Anttonen and H Parviainen contributed equally to this work)

\begin{abstract}
Part of heterodimeric inhibin, inhibin- $\alpha$ is crucial for mammalian ovarian function. Regulation of inhibin- $\alpha$ expression in granulosa cells is both endocrine, primarily by follicle-stimulating hormone (FSH), and paracrine, primarily by members of the transforming growth factor $\beta$ (TGF- $\beta$ ) superfamily. Smad proteins transmit TGF- $\beta$ signals to the nucleus, but the cooperating transcription factors involved in inhibin- $\alpha$ promoter activation remain unknown. Transcription factor GATA-4 regulates inhibin- $\alpha$ in gonadal cells, and the FSH cascade activates GATA- 4 . We hypothesized that the TGF- $\beta$ signalling cascade and GATA-4 also cooperate to regulate inhibin- $\alpha$ expression. In KK-1 granulosa tumour cells, which resemble normal granulosa cells and express inhibin- $\alpha$, we found that TGF- $\beta$ upregulated GATA-4 expression. Transient transfection experiments in KK-1 cells demonstrated that dominant negative GATA-4 variants or mutations of GATA-binding sites in the inhibin- $\alpha$ promoter attenuated TGF- $\beta$-induced gene activation. In GATA-4-deficient COS-7 cells, TGF- $\beta$ enhanced the expression of the inhibin- $\alpha$ promoter only in the presence of exogenous GATA-4. Smad3, but not Smad2, cooperated with GATA-4 in the transcriptional activation of the inhibin- $\alpha$ promoter, and immunoprecipitation experiments in KK-1 cells revealed a physical Smad3:GATA-4 interaction. Our data suggest that GATA-4, interacting with Smad3, is a cofactor for TGF- $\beta$ signalling to activate inhibin- $\alpha$ in granulosa cells.
\end{abstract}

Journal of Molecular Endocrinology (2006) 36, 557-568

\section{Introduction}

Inhibin- $\alpha$ produced by granulosa cells is essential for proper functioning of the mammalian ovary. The secreted inhibins are heterodimers of this common $\alpha$-subunit and either a $\beta \mathrm{A}$ - or a $\beta \mathrm{B}$-subunit (inhibins A and $\mathrm{B}$ respectively) and are important endocrine regulators that repress follicle-stimulating hormone (FSH) secretion by the pituitary through a negative feedback loop. Inhibins, which belong to the transforming growth factor beta (TGF- $\beta$ ) superfamily, are also essential paracrine regulators in ovarian cells (reviewed by Findlay et al. 2001). TGF- $\beta$ signalling is central for a number of cellular processes, including differentiation, proliferation and apoptosis (reviewed by Massague et al. 2000). Inhibin production by granulosa cells is regulated by endocrine (FSH), paracrine (growth differentiation factor-9 (GDF-9)), and autocrine (TGF- $\beta$ and activin) factors (Lanuza et al. 1999, Drummond et al. 2000, Findlay et al. 2001, Kaivo-Oja et al. 2003, Roh et al. 2003).

TGF- $\beta$ signalling is mediated through two types of serine/threonine kinase receptors (Massague et al.
2000). In brief, the ligand binds to a type II receptor, which then heteromerizes with a type I receptor, also termed activin-receptor-like kinase (ALK). This complex then activates Smad proteins, the common intracellular TGF- $\beta$ signal mediators, as well as other pathways, such as the P38 mitogen-activated protein kinase (MAPK) pathway (Hanafusa et al. 1999). The Smad proteins form complexes, translocate into the nucleus, and drive expression of target genes by interacting with cell-specific transcription factors (Massague et al. 2000). Considering the functional diversity of TGF- $\beta$ signalling, it is striking that only two types of Smad responses are known: the bone morphogenic protein type signal activates Smadl, Smad5 and Smad8, whereas the TGF- $\beta$ type signal activates Smad2 and Smad3 (Massague et al. 2000). Thus, the participation of cell-specific, DNA-binding cofactors is likely to be essential. In granulosa cells, oocyte-derived GDF-9 activates the TGF- $\beta$ type pathway (Kaivo-Oja et al. 2003, Roh et al. 2003, Mazerbourg et al. 2004), but the transcription factors that are involved in the activation of target genes has remained unknown. 
Transcription factor GATA-4 has emerged as a potent activator of several genes expressed in endocrine tissues, including anti-Müllerian hormone, aromatase, luteinizing hormone receptor, inhibin- $\beta B$ and inhibin- $\alpha$ (Ketola et al. 1999, Tremblay \& Viger 1999, 2001, Feng et al. 2000, Rahman et al. 2004). GATA-4 belongs to a family of zinc-finger transcription factors, termed the GATAbinding proteins, primarily recognizing a consensus GATA motif in the promoters and enhancers of their target. Interactions between GATA-4 and the Friend of GATA (FOG) family of coactivators/corepressors are essential for the differentiation of several tissues (Tsang et al. 1998, Tevosian et al. 2000, Chang et al. 2002), including gonads (Tevosian et al. 2002). In endocrine cells, gonadotropin signalling through the cAMP-protein kinase A (PKA) pathway leads to phosphorylation of the GATA-4 protein, increasing its DNA binding and thereby its transactivation of the target genes (Tremblay \& Viger 2003a,b). Furthermore, FSH upregulates GATA-4 expression in cultured granulosa tumour cells (Heikinheimo et al. 1997).

In recent years, we have detailed the expression of GATA-4 in mouse and human granulosa cells and granulosa cell tumours (Heikinheimo et al. 1997, Laitinen et al. 2000, Vaskivuo et al. 2001, Anttonen et al. 2003, 2005). In the postnatal ovary, GATA-4 expression is initiated in the primary follicular stage and maintained until the larger antral stage or follicular atresia. Since a Gata4-null mutation is embryonic lethal (Kuo et al. 1997, Molkentin et al. 1997), the ultimate role of GATA-4 in granulosa cell function has remained unknown. Given that GATA factors have recently been reported to cooperate with TGF- $\beta$ signalling in the immune system and the heart (Blokzijl et al. 2002, Brown et al. 2004), we hypothesized that GATA-4 is employed in the TGF- $\beta$-Smad2/3 pathway in granulosa cells.

\section{Experimental procedures}

\section{Reagents and plasmid constructs}

Antibodies (polyclonal goat anti-GATA-4 IgG, sc-1237 and sc-1237X, and polyclonal goat antiactin IgG, sc-1616) were purchased from Santa Cruz Biotechnology (Santa Cruz, CA, USA); polyclonal rabbit anti-Smad3 IgG, 51-1500 from Zymed Laboratories (San Francisco CA, USA); and monoclonal mouse anti-inhibin- $\alpha$ IgG, MCA951S from Serotec (Oxford, UK). Recombinant TGF- $\beta_{1}$ was purchased from R\&D Systems (Minneapolis, MN, USA); FuGene6 from Roche; Lipofectamine 2000 from Invitrogen; luciferase detection system from Promega; $\mathrm{pCMV} \beta$ from Clontech; and protease inhibitor cocktail (P8340) from Sigma-Aldrich. $\gamma-{ }^{32} \mathrm{P}-\mathrm{ATP}$ was purchased from PerkinElmer (Boston, MA, USA); T4 polynucleotide kinase and kinase buffer from New England BioLabs (Beverly,
MA, USA); and polydI-dC from Amersham. Immobilon-P membrane was purchased from Millipore (Bedford, MA, USA); secondary antibody from Jackson Laboratories (West Grove, PA, USA); and Enhanced Chemiluminescence Plus Kit from Amersham. The dominant negative GATA-4 mutant plasmid pMT2GATA-4-DN2 (DN2) was generated by mutating the carboxy-terminal zinc-finger in the sequence coding GATA-4 protein, with the Quick Change Site-Directed Mutagenesis Kit (Stratagene, La Jolla, CA, USA). The following primers were designed to change cysteines into serines in both positions of the zinc-finger:

- wild-type nucleotides 1437-1466, 5'-GAGCGTGT ATGTAATGCGTGCGGCCTCTAC-3'

- mutant nucleotides 1437-1466, 5'-GAGCGTGTA TCTAATGGCTCGGGCGTCTAC-3'.

The changes were confirmed by sequencing, and the integrity of the mRNAs and proteins was confirmed by northern blot and western blot respectively, as described by Arceci et al. (1993). The other plasmids employed have been previously described: pMT2-GATA-4 (wild-type GATA-4) and pMT2-GATA-4-DN1 (DN1) (Arceci et al. 1993), pGL2 -679 bp-inhibin-a-luciferase (Tremblay \& Viger 2001), Flag-pcDEF3-Smad2 and Flag-pcDEF3-Smad4 (Kawabata et al. 1998), FlagpcDNA3-Smad3 (Nakao et al. 1997), pMT2-FOG-1 (Tsang et al. 1997) and pCS2+-FOG-2 (Tevosian et al. 1999). In the wild-type and mutant -180 bp-inhibin- $a-$ luciferase plasmids, we replaced the original pTKGH reporter vector (Ketola et al. 1999) with pGL2 by subcloning to the HindIII sites and sequencing to verify orientation. Of all the plasmids, the corresponding empty plasmid was employed as a control in all experiments.

\section{Cell culture and luciferase assays}

The cells were cultured in $37^{\circ} \mathrm{C}$ in a humidified atmosphere containing $5 \% \mathrm{CO}_{2}$. COS-7 cells were cultured in DMEM supplemented with 10\% fetal bovine serum (FBS), $100 \mathrm{U} / \mathrm{ml}$ penicillin and $100 \mathrm{U} / \mathrm{ml}$ streptomycin. KK-1 cells were originally established from an ovarian tumour of inhibin- $\alpha$-driven, T-antigen transgenic mice, and cultured in DMEM supplemented with $4.5 \mathrm{~g} / \mathrm{l}$ glucose, $0.365 \mathrm{~g} / \mathrm{l}$ L-glutamine, $20 \mathrm{mM}$ Hepes, $100 \mathrm{U} / \mathrm{ml}$ penicillin and $100 \mathrm{U} / \mathrm{ml}$ streptomycin. In luciferase assays, the cells were plated at a density of $1.5 \times 10^{5} \quad(\mathrm{COS}-7)$ or $2.5 \times 10^{5} \quad(\mathrm{KK}-1)$ cells/well on 12-well plates and grown for $24 \mathrm{~h}$ before transfection. In TGF- $\beta$ stimulations, the cells were treated with $0,10,20$ or $50 \mathrm{ng} / \mathrm{ml}$ TGF- $\beta_{1}$ in $1 \%$ or $10 \%$ FBS. COS-7 cells were transfected with FuGene6 and KK-1 cells with Lipofectamine 2000 according to manufacturers' instructions. The expression of all transfected plasmids was verified by western blotting. In all experiments, $\mathrm{pCMV} \beta$-galactosidase was 
cotransfected to monitor transfection efficiency. When protein-expressing plasmids were transfected, the equal amount of corresponding empty plasmids was transfected to all the other wells. Cells were lysed $40 \mathrm{~h}$ (COS-7) or $48 \mathrm{~h}(\mathrm{KK}-1)$ after transfection, and a luciferase assay normalized to $\beta$-galactosidase activity was performed, as previously described (Martelin et al. 2000).

\section{Nuclear extracts and electrophoretic mobility shift analysis (EMSA)}

Nuclear extracts of lysates of COS-7 and KK-1 cells were prepared and protein concentrations measured, as previously described (Martelin et al. 2000), with the minor modification that separate protease inhibitors were replaced with protease inhibitor cocktail at a concentration suggested by the manufacturer. Oligonucleotide probes were for the area around the two GATA sites on the wild-type or mutant inhibin-a promoter (Ketola et al. 1999) - inha1, 5'GTGGGA GATAAGGGTC3'; inhal mut, 5'GTGGGACATA AGGCTC3'; inha2, 5'GTCAGAGATAGGAGGT3'; inha2 mut, 5' GTCAGACATAGGAGGT3' - and the complementary strands. The oligos were end-labelled with $\gamma_{-}{ }^{32} \mathrm{P}$-ATP, using T4 polynucleotide kinase, and annealed to dimers. In binding reactions, $10 \mu \mathrm{g}$ nuclear protein were incubated with 10000-30 000 c.p.m. of the labelled probe for $5 \mathrm{~min}$ on ice in $10 \mathrm{mM}$ Hepes $(\mathrm{pH}$ $7 \cdot 8$ ), $1 \mathrm{mM}$ EDTA, $5 \mathrm{mM} \mathrm{MgCl}_{2}, 5 \%$ glycerol, $1 \mathrm{mM}$ DTT and $1 \mu \mathrm{g}$ poly-dIdC. In competition experiments, a 100-fold excess of unlabelled wild-type or mutant probe was added before the labelled probe, and in supershift experiments, the incubation was further continued with $1-2 \mu \mathrm{g}$ of antibody (sc-1237X or anti-GATA-4 IgG, as described by Arceci et al. (1993)) for $10 \mathrm{~min}$. Total reaction volume was $20 \mu \mathrm{l}$. The samples were loaded on a $5 \%$ acrylamide gel in $0.5 \mathrm{x}$ TBE, run with $200 \mathrm{~V}$ for $1 \cdot 75-2 \mathrm{~h}$ at room temperature, and visualized by autoradiography.

\section{Co-immunoprecipitation}

COS-7 cells were transfected to coexpress equal amounts of GATA-4 and/or Smad3 proteins. Aliquots $(100 \mu \mathrm{g})$ of COS-7 or KK-1 nuclear extracts were immunoprecipitated by end-over-end mixing overnight at $4{ }^{\circ} \mathrm{C}$ with anti-GATA-4 (sc-1237) or anti-Smad3 (51-500) in PBS supplemented with $1 \%$ NP40, $1 \mathrm{mM}$ EDTA, and protease inhibitor cocktail. The protein complexes were collected by adding protein G-Sepharose for $1 \mathrm{~h}$ followed by five washes with the buffer, and subjected to SDS-PAGE. Non-specific antibodies were employed in control experiments.

\section{Western blotting}

Nuclear proteins of COS-7 $(10 \mu \mathrm{g})$ or KK-1 $(40 \mu \mathrm{g})$ cells or, alternatively, the precipitated proteins (see above) were separated by $7 \cdot 5 \%$ SDS-PAGE and transferred to Immobilon-P membrane. The non-specific antibody binding was blocked with $5 \%$ skim milk in $0 \cdot 1 \%$ Tween-TBS buffer. The membrane was incubated with primary antibody (sc-1237, 51-1500 or sc-1616) for $1 \mathrm{~h}$ at room temperature, followed by secondary antibody, and visualized by the Enhanced Chemiluminescence Plus Kit. For controls, the membranes were subsequently stripped and reprobed.

\section{Immunohistochemistry}

Samples of three normal human ovaries, removed because of cervical cancer from women under 35 years, were embedded in paraffin-wax and sectioned to $5 \mu \mathrm{m}$. Immunohistochemical staining was performed on the sections, as previously described (Anttonen et al. 2003), with the primary antibodies anti-GATA-4 (sc-1237, dilution 1:200), anti-Smad3 (51-1500, dilution 1:100) and anti-inhibin- $\alpha$ (MCA951S, dilution 1:20). In immunocytochemical staining of KK-1 cells, the cells were grown to form a monolayer, fixed in 4\% PFA, and stained with a similar procedure as for the tissue sections. The Helsinki University Central Hospital ethics committee approved the use of the human tissue samples.

\section{Data analysis}

All experiments were repeated at least three times. Cell cultures were performed in triplicate, and results are presented as the mean \pm S.E.M. of three independent experiments.

\section{Results}

TGF- $\beta$ upregulates GATA-4 protein levels and activates the inhibin- $\alpha$ promoter in KK-1 cells

To test the hypothesis that GATA-4 is involved in TGF- $\beta$-Smad2/3 type signalling in granulosa cells, we utilized KK-1 cells. This cell line, originally derived from a murine granulosa cell tumour (Kananen et al. 1995), retains features of normal granulosa cells, including expression of inhibin- $\alpha$, steroidogenic factor- 1 (SF-1) and GATA-4 (Fig. 1A, and data not shown). However, the passages utilized did not respond to gonadotrophins (Kananen et al. 1995). We found that the level of GATA-4 protein in KK-1 cells increased in response to TGF- $\beta$ stimulation for $1 \cdot 5,3$ or $24 \mathrm{~h}$ (Fig. 1A). In addition, TGF- $\beta$ stimulation led to an increase in the levels of Smad 2 and Smad 3 in the nucleus, confirming 
A

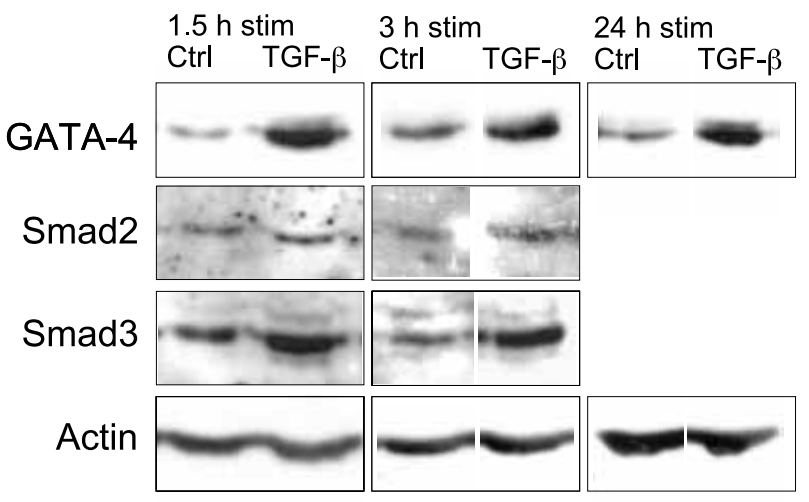

C

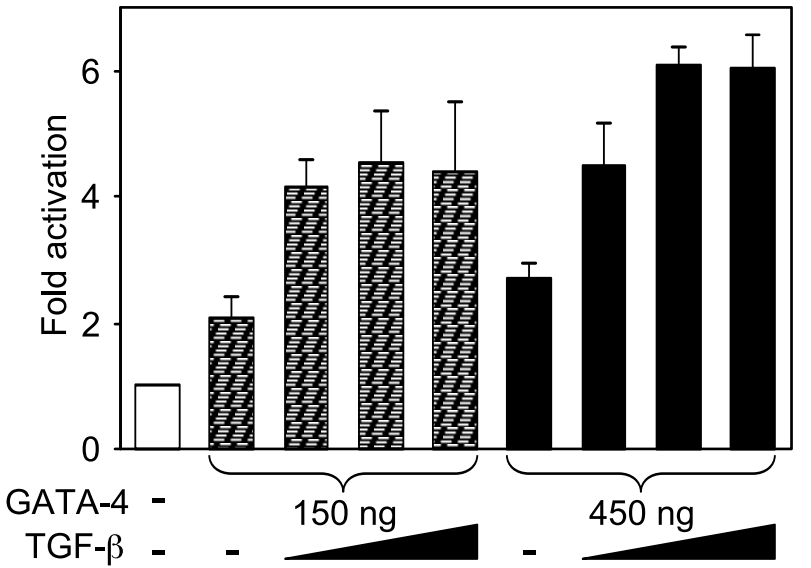

B

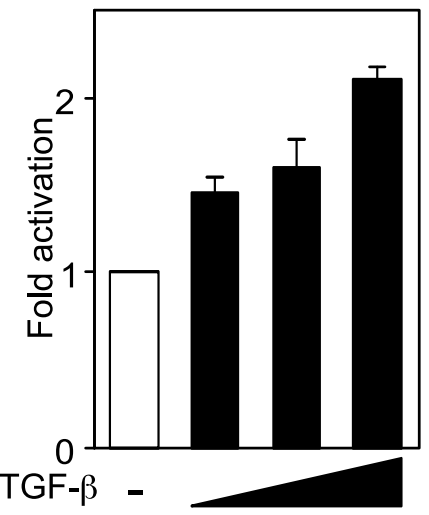

D

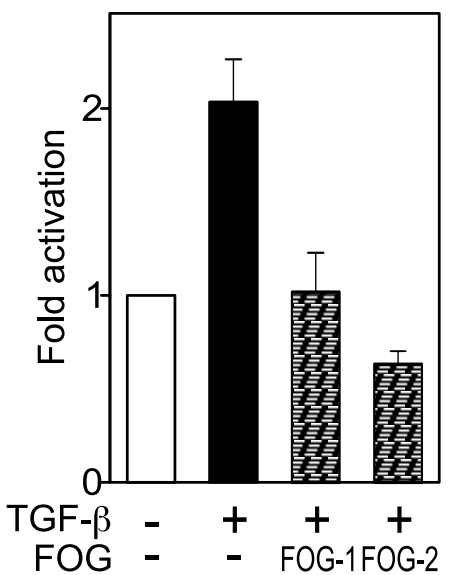

Figure 1 TGF- $\beta$ upregulates GATA-4 protein levels and the inhibin- $\alpha$ promoter in KK-1 cells. (A) Western blot analysis of GATA-4, Smad2 and Smad3 protein expression in KK-1 cell nuclear extracts, treated with 0 or $20 \mathrm{ng} / \mathrm{ml} \mathrm{TGF}-\beta$ in $1 \%$ FBS for $1.5,3$ or $24 \mathrm{~h}$. Actin protein levels were analysed to control equal loading. (B) KK-1 cells were transiently transfected with a construct of a $-679 \mathrm{bp}$ fragment of the inhibin- $\alpha$ promoter coupled to a luciferase reporter (inha-luc), and stimulated with 0,2 , 10 or $50 \mathrm{ng} / \mathrm{ml} \mathrm{TGF-} \beta$ in $1 \%$ FBS for $24 \mathrm{~h}$. (C) GATA-4 expression plasmid or the corresponding empty plasmid was introduced into the setting in two different amounts. (D) KK-1 cells were transiently transfected with the inha-luc construct, in the presence of GATA-4, FOG-1 and FOG-2 expression plasmids, or the corresponding empty plasmids, and stimulated with 0 or $50 \mathrm{ng} / \mathrm{ml} \mathrm{TGF-} \beta$ in $1 \%$ FBS for $24 \mathrm{~h}$. Luciferase activity is normalized to $\beta$-galactosidase activity and presented relative to control as the mean \pm S.E.M. of three independent experiments performed in triplicate.

their activation and translocation to this compartment (Fig. 1A).

Next, we performed transient transfection studies with a -679 bp inhibin- $\alpha$ gene promoter coupled to a luciferase reporter. This promoter fragment was active in KK-1 cells, and TGF- $\beta$ stimulated the activity of this promoter in a dose-dependent fashion up to two-fold (Fig. 1B). Although GATA-4 is endogenous to KK-1 cells, overexpression of GATA-4 via transfection enhanced the TGF- $\beta$ effect up to sixfold (Fig. 1G). The GATA cofactors, FOG-1 or FOG-2, can repress promoter activation by GATA-4 in in vitro assays (Robert et al. 2002). Although FOG-1 was found to be endogenous to KK-1 cells (data not shown), forced expression of either FOG-1 or FOG-2 abolished inhibin- $\alpha$ promoter activation by TGF- $\beta$ in KK-1 cells (Fig. 1D); furthermore, FOG-2 downregulated the promoter activity one-third below the basal level. The endogenous FOG-1 expression might also influence transfection efficiency in the KK-1 cell model, causing the relatively low-fold activations achieved. These effects are altogether likely to occur through interaction with endogenous GATA factors. The abrogation of TGF- $\beta$ response of the inhibin- $\alpha$ promoter by FOG- 2 thus 
indirectly supports the involvement of a GATA factor, presumably GATA-4, in this pathway.

\section{Proper GATA-4 function is required for inhibin- $\alpha$ promoter activation by TGF- $\beta$}

Introduction of dominant negative GATA-4 mutants into KK-1 cells allowed us to determine whether endogenous GATA-4 mediates the stimulatory effects of TGF- $\beta$ on the inhibin- $\alpha$ promoter. Two mutant constructs were employed; the first one (termed DN1) lacked the N-terminal activation domain, and the second (DN2) had mutations in the cysteines of the $\mathrm{C}$-terminal zinc-finger, which is required for DNA binding (Morrisey et al. 1997) and interaction with a number of cofactors, including Smads (Brown et al. 2004). In electrophoretic mobility shift analyses (EMSA), transfected wild-type and DN1 GATA-4 bound to both of the GATA-sites on the inhibin- $\alpha$ promoter (Fig. 2A), whereas DN2 bound to neither (data not shown). Transfecting the mutants into KK-1 cells did not alter the basal activity of the inhibin- $\alpha$ promoter (Fig. 2B). Both mutants were, however, able to inhibit the TGF- $\beta$-induced, $2 \cdot 5$-fold increase in the promoter activity; the DN2 mutant suppressed this increase by half. The inability of the mutants to suppress completely the TGF- $\beta$ effect is probably due to the increase in GATA-4 protein caused by TGF- $\beta$ (Fig. 1A).

For clarification of the role of GATA- 4 in TGF- $\beta$ signalling, we addressed the necessity of the two GATA-binding sites in the inhibin- $a$ promoter. The first, the second, or both sites were mutated (termed mutl, mut2, and mutl and 2) (Fig. 2C). As with the longer $-679 \mathrm{bp}$ promoter fragment studied in the previous experiments, TGF- $\beta$ stimulated this more proximal -166 bp promoter by two-fold. Introduction of GATAbinding site mutations resulted in abrogation of the TGF- $\beta$ effect (Fig. 2C). Furthermore, when both of the GATA sites were mutated, the overall promoter activity was only one-third that of the wild-type promoter activity in KK-1 cells (Fig. 2C, column 7 vs 1). All in all, these results highlight the essential role of a granulosa cell GATA protein, probably GATA-4, bound to its consensus sites, both in the basal activity and in the TGF- $\beta$ response of the inhibin- $\alpha$ promoter.

\section{GATA-4 enables inhibin- $\alpha$ promoter activation in COS-7 cells}

COS-7 cells with or without TGF- $\beta$ stimulation did not express GATA factors as studied by western blot or immunocytochemistry (data not shown), allowing us to test directly the impact of GATA-4 on the inhibin- $\alpha$ promoter activation by TGF- $\beta$. Western blot demonstrated Smad2 and Smad3 expression in these cells (data not shown), and they did respond to TGF- $\beta$ treatment, monitored by a CAGA-luciferase reporter that is activated by a TGF- $\beta$-Smad3 type signal (Dennler $e$ al . 1998, Mazerbourg et al. 2004). To activate the inhibin-a promoter in these cells, however, forced expression of GATA-4 was needed (Fig. 3A). After introduction of GATA-4, TGF- $\beta$ was able to activate the promoter up to 22 -fold. As in KK-1 cells, forced expression of FOG-1 or FOG-1 diminished the ability of TGF- $\beta$ to activate the inhibin- $\alpha$ promoter (Fig. 3B).

\section{Functional interaction of Smad3 and GATA-4 mediates inhibin-a promoter activation}

The cooperation of GATA- 4 and the TGF- $\beta$ cascade was further dissected by coexpressing GATA-4 and the Smad proteins in COS-7 cells. Overexpression of an equal amount of Smad2 or Smad3, verified by Western blot (data not shown), failed to activate substantially the inhibin- $\alpha$ promoter, even after TGF- $\beta$ stimulation (Fig. $3 \mathrm{C}-\mathrm{D})$. This might indicate a lack of cooperating transcription factors or other modulators in the COS-7 cells. However, introduction of GATA-4 to this setting resulted in 45-fold promoter activation with Smad3 (Fig. 3D). TGF- $\beta$ stimulation or driven expression of the coactivating Smad4 did not further increase the effect of GATA-4 and Smad3 (Fig. 3E and data not shown), while both FOG-1 and FOG-2 downregulated the GATA-4:Smad3 effect to the basal level of promoter activity (Fig. 3E). Thus, Smad3, together with GATA-4, appears to be sufficient to activate the inhibin-a promoter.

Next, we introduced the mutant GATA- 4 constructs with Smad3 into COS-7 cells (Fig. 3F). Overexpression of Smad3 with DN1, lacking the N-terminal end but having a normal zinc-finger region, resulted in promoter activation comparable to that achieved with the wild-type GATA-4. In contrast, overexpression of DN2, having the $\mathrm{C}$-terminal zinc-finger abolished, failed to activate the promoter either alone or with Smad3. These results suggest that the $\mathrm{C}$-terminal zinc-finger region in GATA-4 is important in the promoter activation with Smad3, and that the N-terminal end of GATA-4 is not crucial for the functional interaction.

\section{Smad3 colocalizes with GATA-4 and inhibin- $\alpha$ in granulosa cells}

The physiological relevance of GATA- 4 in TGF- $\beta$ signalling was underscored by immunohistochemical studies. Staining of an adult human ovarian tissue sample demonstrated the colocalization of inhibin- $\alpha$, GATA-4 and Smad3 in granulosa cells, especially in preantral and small antral follicles (Fig. 4A-C). Furthermore, Smad3 was predominantly found in the nuclei (Fig. 4C), a sign of its active function in granulosa cells in vivo. In KK-1 cells, the situation was identical for 
A

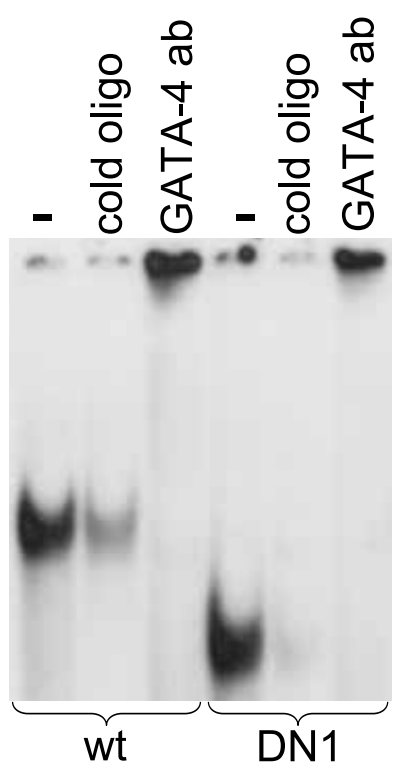

C
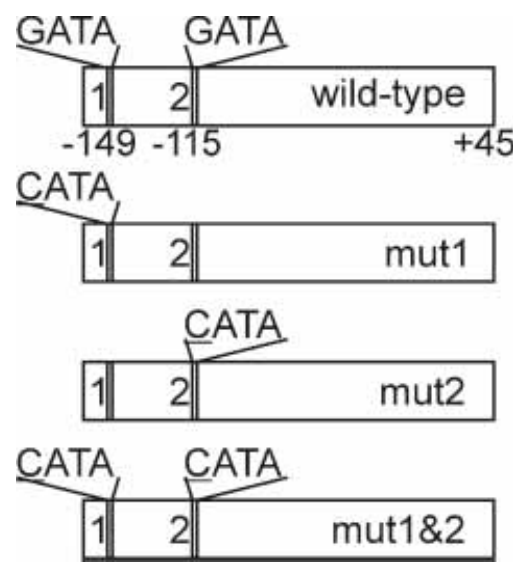

B

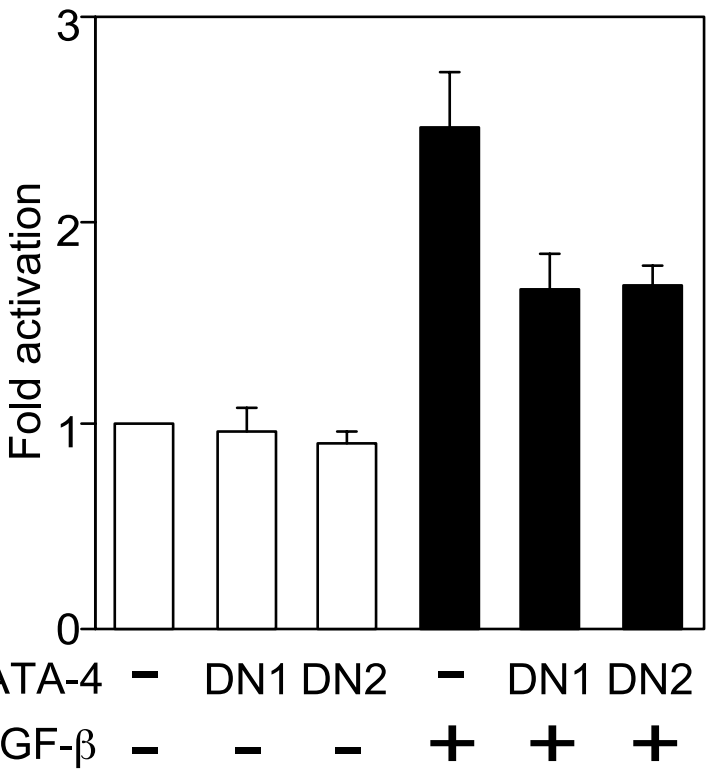

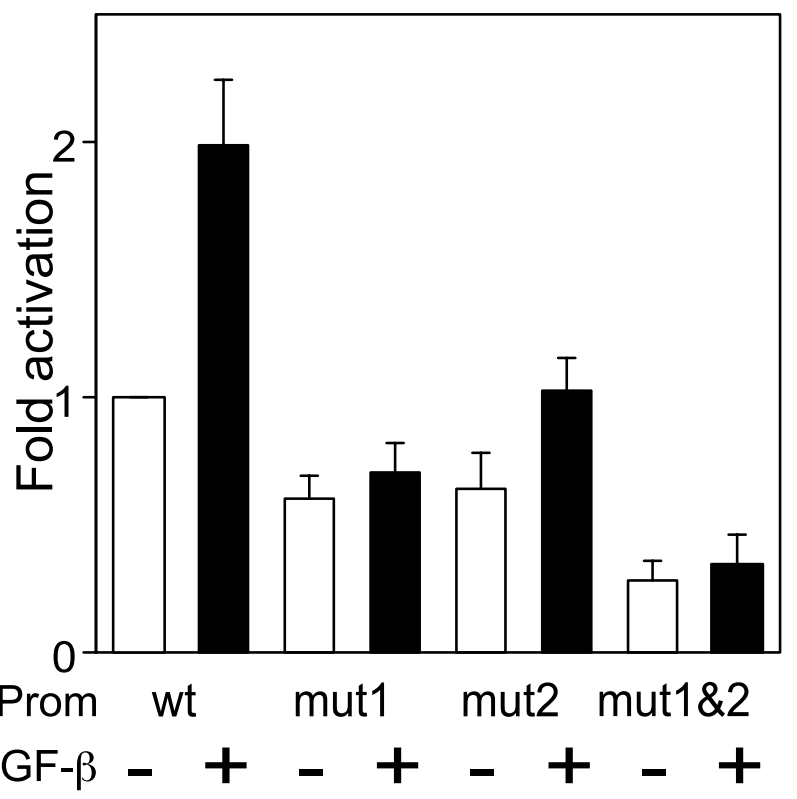

Figure 2 Proper GATA-4 function is essential for inhibin- $\alpha$ promoter stimulation in KK-1 cells. (A) COS-7 cells were transfected with a wild-type or mutated GATA-4 expression plasmids (wt, DN1, and DN2) or the corresponding empty plasmids. DN1 lacked the N-terminal end of GATA-4 protein, and DN2 had the cysteines mutated on the C-terminal zinc-finger. EMSA was performed with a radiolabelled $16 \mathrm{bp}$ oligo of the $5^{\prime}$ GATA site in the inhibin- $\alpha$ promoter $(\mathrm{C})$ as a probe, and either a 100 -fold excess of unlabelled probe or GATA-4 antibody for supershift was added, as indicated. DN2 did not bind to the oligo (data not shown). Similar results were obtained with the 3' GATA site. (B) KK-1 cells were transiently transfected with the inha-luc construct, in the presence of DN1 and DN2, or the corresponding empty plasmids. The cells received 0 or $10 \mathrm{ng} / \mathrm{ml} \mathrm{TGF}-\beta$ in $1 \%$ FBS for $24 \mathrm{~h}$. (C) KK-1 cells were transiently transfected with a -166 bp wild-type or mutant inhibin- $\alpha$ promoter/luciferase reporter construct. The cells received 0 or $10 \mathrm{ng} / \mathrm{ml} \mathrm{TGF-} \beta$ in $1 \%$ FBS for $24 \mathrm{~h}$. In mut1, the 5' GATA site was mutated by replacing nucleotide $G$ with $C$; in mut2, the $3^{\prime}$ GATA-site; and in mut1 and 2, both. Luciferase activity is normalized to $\beta$-galactosidase activity and presented relative to control as the mean \pm S.E.M. of three independent experiments performed in triplicate. 
A

B
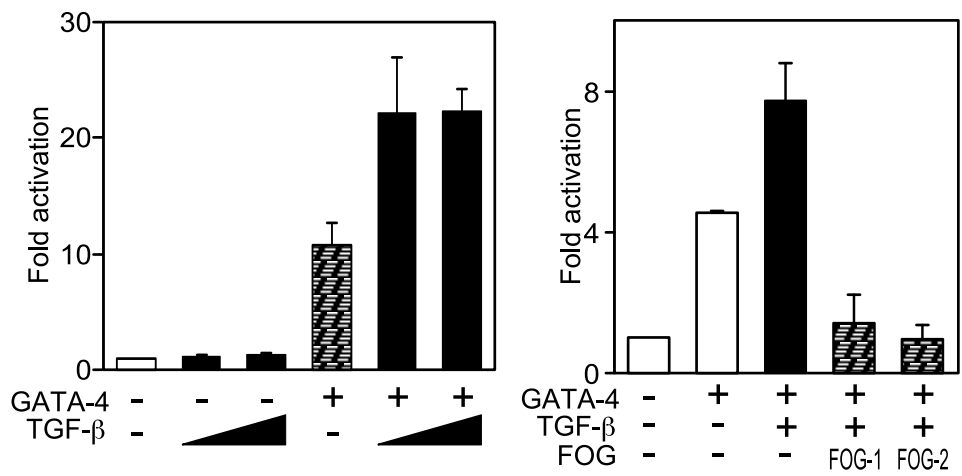

C

D

$E$
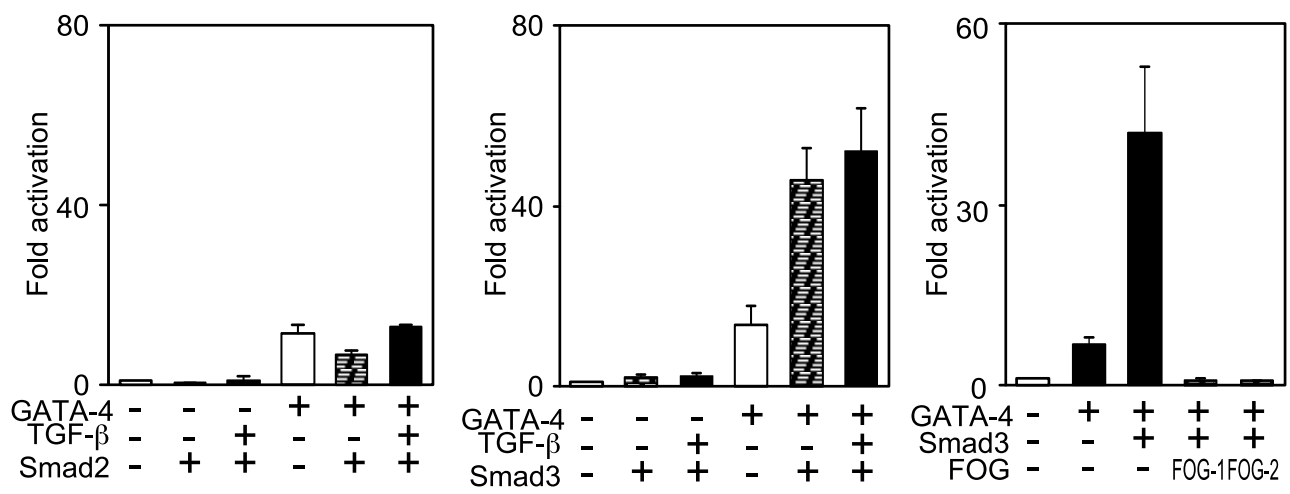

$\mathbf{F}$

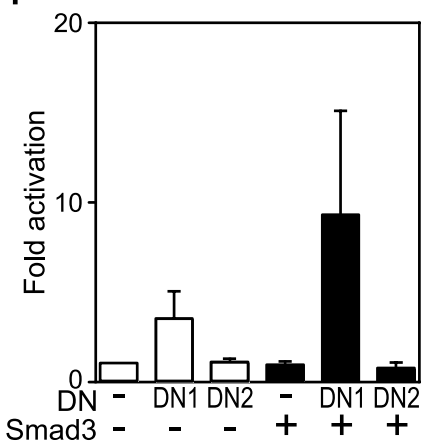

Figure 3 GATA-4 enables inhibin- $\alpha$ promoter activation in COS-7 cells. (A) COS-7 cells were transiently transfected with the inha-luc construct, in the presence of GATA-4 expression plasmid or the corresponding empty plasmid, and stimulated with 0,2 or $10 \mathrm{ng} / \mathrm{ml}$ TGF- $\beta$ in $1 \%$ FBS for $24 \mathrm{~h}$. (B) COS-7 cells were transiently transfected with the inha-luc construct, in the presence of GATA-4, FOG-1 and FOG-2 expression plasmids, or the corresponding empty plasmids, and stimulated with 0 or $10 \mathrm{ng} / \mathrm{ml} \mathrm{TGF-} \beta$ in $1 \%$ FBS for $24 \mathrm{~h}$. (C and D) COS-7 cells were transiently transfected with the inha-luc construct, in the presence of GATA-4, Smad2 and Smad3 expression plasmids, or the corresponding empty plasmids, and stimulated with 0 or $10 \mathrm{ng} / \mathrm{ml} \mathrm{TGF-} \beta$ in $1 \%$ FBS for $18 \mathrm{~h}$. (E) COS-7 cells were transiently transfected with the inha-luc construct, in the presence of GATA-4, Smad3, FOG-1 and FOG-2 expression plasmids, or the corresponding empty plasmids. (F) COS-7 cells were transiently transfected with the inha-luc construct, in the presence of dominant negative GATA-4 constructs DN1 (lacking the N-terminal end) or DN2 (C-terminal zinc-finger mutated), Smad3 expression plasmids or the corresponding empty plasmids. The fold activation of the promoter when wild-type GATA-4 and Smad3 were cotransfected in this experiment was lower than in the experiments shown in panels C-E, by approximately 10 -fold (not shown). Luciferase activity is normalized to $\beta$-galactosidase activity and presented relative to control as the mean \pm standard error of the mean (S.E.M.) of three independent experiments performed in triplicate. 

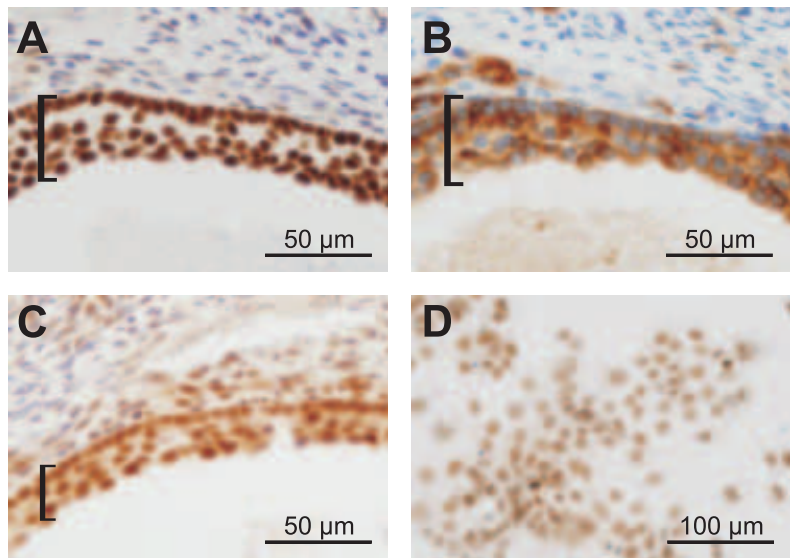

Figure 4 The intracellular TGF- $\beta$ signal mediator Smad3 colocalizes with GATA- 4 and inhibin- $\alpha$ in human granulosa cells. (A-C) High-power magnification view of a human ovarian tissue section, showing a part of a small antral follicle of $500 \mu \mathrm{m}$ in diameter. The vertical bar indicates granulosa cells. The tissue section was subjected to immunoperoxidase staining with antibodies against GATA-4 (A), inhibin- $\alpha$ (B) or Smad3 (C) protein. Sections were counterstained with haematoxylin. A region expressing the antigen stains brown, whereas a negative region stains blue. (D) High-power magnification view of KK-1 mouse granulosa tumour cells grown to form a monolayer, subjected to immunoperoxidase staining with antibody against Smad3 protein and counterstained with haematoxylin.

Smad3 (Fig. 4D). These findings extend previous studies on Smad3 expression in granulosa cells (Xu et al. 2002, Bristol \& Woodruff 2004), and support a role for Smad3 as an active transcriptional regulator in the granulosa cell nucleus.

\section{Smad3 and GATA-4 exhibit endogenous physical interaction in KK-1 cells}

As in COS-7 cells, the functional GATA-4:Smad3 interaction was also observed in KK-1 cells, as exogenous GATA-4 and/or Smad3 increased the effect of TGF- $\beta$ on the inhibin- $\alpha$ promoter (Fig. 5A). Since these proteins are also colocalized in granulosa cells of growing ovarian follicles (Fig. 4), we next investigated whether they interact at the protein level. COS-7 cells were transiently transfected to overexpress equal amounts of GATA-4, Smad3 or both proteins. When GATA-4 alone or both proteins were coexpressed in the COS-7 cells, Smad3 antibody was able to precipitate the GATA-4 protein in the nuclear extracts (Fig. 5B). These findings indicate that Smad3 and GATA-4 physically interact in the cell nucleus. In KK-1 granulosa cells, GATA-4:Smad3 interaction was evident endogenously, as identified by immunoprecipitating KK-1 nuclear extracts with Smad3 antibody and detecting GATA-4 by western blot (Fig. 5G). TGF- $\beta$ administration had no effect on this interaction (data not shown). Considering the predominantly nuclear localization of Smad3 and GATA-4 in granulosa cells in vivo (Fig. 4), this finding supports the premise that GATA-4 is involved in Smad3-dependent transcription in the granulosa cells.

\section{Discussion}

Signalling pathways activated by TGF- $\beta$ superfamily ligands affect various cellular processes and require a number of tissue-specific transcription factors (Massague et al. 2000). We have now shown a role for transcription factor GATA-4 in the TGF- $\beta$-type pathway in granulosa cells, activated in vivo by TGF- $\beta$, activin and GDF-9. Studying a mouse granulosa cell model retaining many of the features of primary granulosa cells, we observed an increase in the amount of GATA-4 protein after stimulation with TGF- $\beta$. This phenomenon suggests a self-stimulatory effect of TGF- $\beta$ signalling to achieve effective transcriptional activity for prolonged periods. Such self-enabling responses have been described elsewhere; for example, the expression of a transcriptional repressor ATF3, which acts with TGF- $\beta$ signalling to repress $I d 1$ in epithelial cells, was increased by TGF- $\beta$ signalling (Kang et al. 2003). Furthermore, induction of Gata 4 by TGF- $\beta$ family signalling has been observed in Xenopus organ culture studies (Ariizumi et al. 2003) and in mouse stem cells ( $\mathrm{Li}$ et al. 2005). These results emphasize that GATA-4 is one of the key factors involved in the TGF- $\beta$ induction of cardiac cell differentiation.

Our results suggest that GATA-4 is involved in the cascade transmitting the TGF- $\beta$ type signal to the inhibin- $a$ promoter in granulosa cells. Overexpression of FOG-1 or FOG-2 attenuated the inhibin- $\alpha$ promoter activation, supporting the role of GATA proteins in this process. FOG proteins have been reported both to coactivate (Tsang et al. 1997) and repress (Svensson et al. 2000) GATA action. Dominant negative GATA-4 variants or mutation of GATA-binding sites in the inhibin- $\alpha$ promoter abrogated the TGF- $\beta$ responsiveness, indicating that GATA-4 is required for inhibin-a activation. Given also that TGF- $\beta$ signalling upregulated GATA-4, these data suggest that GATA-4 is a granulosa cell-specific cofactor for this pathway.

Interactions between TGF- $\beta$ signal mediators and GATA factors have recently been reported in the cells of the immune system and the heart: GATA-3 and Smad3 cooperated in $\mathrm{T}$ helper cells to activate interleukin 5 (Blokzijl et al. 2002), and $\mathcal{N k x 2 . 5}$ was activated in synergism of GATA-4 and Smadl/4 in cardiac cells (Brown et al. 2004). In gonadal cells, we now found that GATA-4 and Smad3 cooperate in transmitting the TGF- $\beta$ signal to activate inhibin- $\alpha$. In accordance with the findings by Brown et al., this interaction seems to require the C-terminal zinc-finger region of the 
GATA-4. We found Smad2 and Smad3 to behave differently in the reporter assays. The observed strong effect of Smad3 compared with the lack of effect of Smad2 is supported by the fact that a Smad3-null mutation causes downregulation of inhibin- $a$ expression in the ovary (Tomic et al. 2004). This may suggest that in

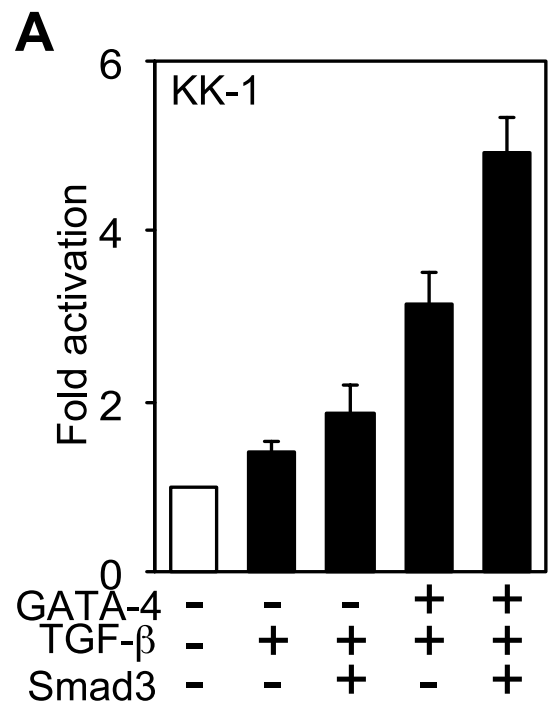

B Transfected COS-7
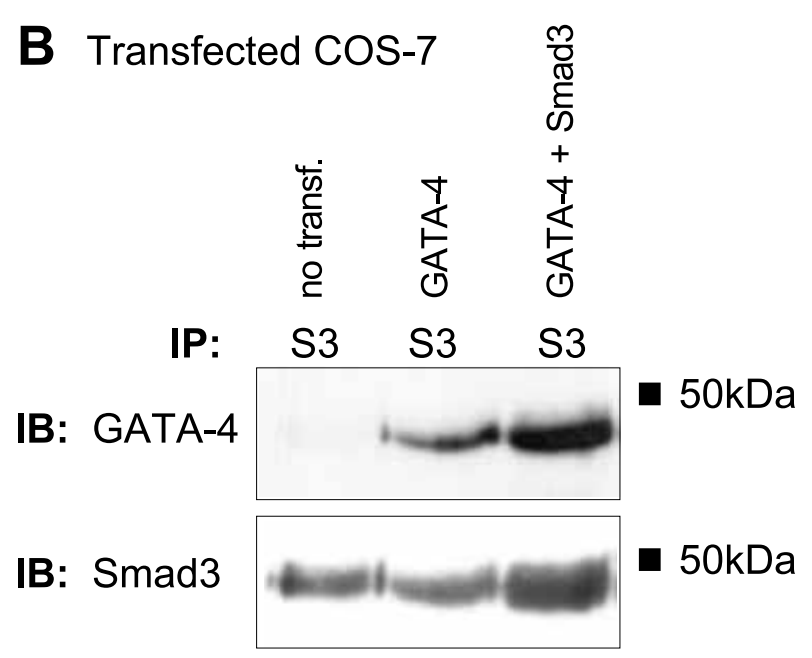

C KK-1

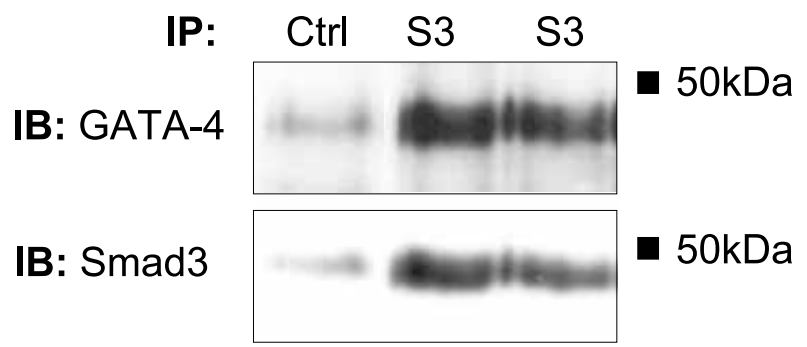

this context Smad2 is unable to compensate for the loss of Smad3. It has also been reported that Smad2 occurs in most cells in two different alternatively spliced forms, of which the shorter retains DNA-binding activity similar to Smad3 (Dunn et al. 2005). We utilized the longer form of Smad2, which may require additional cofactors to function properly with distinct promoters. As Smad3 binds to DNA only with a low affinity (Shi et al. 1998), tissue-specific cofactors are essential for efficient promoter binding and activation. The endogenous physical GATA-4:Smad3 interaction in KK-1 cells suggests such a role for GATA-4 in granulosa cells.

Inhibin production in the granulosa cells is regulated by endocrine and paracrine/autocrine factors. Of the latter, GDF-9 and activin upregulate inhibin production in primary granulosa cells, utilizing the TGF- $\beta$ type Smad2/Smad3 signal pathway (Kaivo-Oja et al. 2003, Roh et al. 2003, Mazerbourg et al. 2004). The present and previous results suggest that GATA- 4 is utilized in both the endocrine FSH pathway and the paracrine TGF- $\beta$ pathway to activate inhibin- $\alpha$ in these cells (Fig. 6):

1) The FSH-activated PKA phosphorylates and activates GATA-4 (Tremblay \& Viger 2003a,b).

2) Both FSH and TGF- $\beta$ upregulate GATA-4 transcription (Heikinheimo et al. 1997, this study).

3) The TGF- $\beta$ signal mediator Smad3 cooperates with GATA-4 (this study).

It is also of interest that TGF- $\beta$ activates PKA (Zhang et al. 2004) and p38 MAPK (Hanafusa et al. 1999); both of these kinases are connected to the activation of GATA-4 (Pikkarainen et al. 2003, Tremblay \& Viger $2003 b$ ). The TGF- $\beta$-induced upregulation of GATA-4 expression could thus be independent of Smad proteins.

The commercially available TGF- $\beta$ utilized in our in vitro studies as an activator of the TGF- $\beta$ pathway may not be the optimal ligand for promoting transcription of the inhibin- $\alpha$ gene. Two other members of the TGF- $\beta$ family, GDF-9 and activin, have been linked to inhibin
Figure 5 Smad3 and GATA-4 interact on protein level. (A) $\mathrm{KK}-1$ cells were transiently transfected with the inha-luc construct, in the presence of GATA-4, Smad2 and Smad3 expression plasmids, or the corresponding empty plasmids, and stimulated with 0 or $50 \mathrm{ng} / \mathrm{ml}$ TGF $-\beta$ in $1 \%$ FBS for $24 \mathrm{~h}$. Luciferase activity is normalized to $\beta$-galactosidase activity and presented relative to control as the mean \pm S.E.M. of three independent experiments performed in triplicate. (B) COS-7 cells were transfected with GATA-4 and Smad3 as indicated. Nuclear protein extracts were immunoprecipitated (IP) with anti-Smad3 (S3), followed by immunoblot (IB) with GATA-4 antibody, and with Smad3 antibody for control. (C) Nuclear protein extracts of KK-1 cells were immunoprecipitated with non-specific IgG for control (Ctrl) or anti-Smad3, followed by immunoblot (IB) with GATA-4 and Smad3 antibodies. In both panels $A$ and $B$, the blots were stripped prior to the control detection with the precipitation antibody; similar results were obtained in at least three independent experiments. 


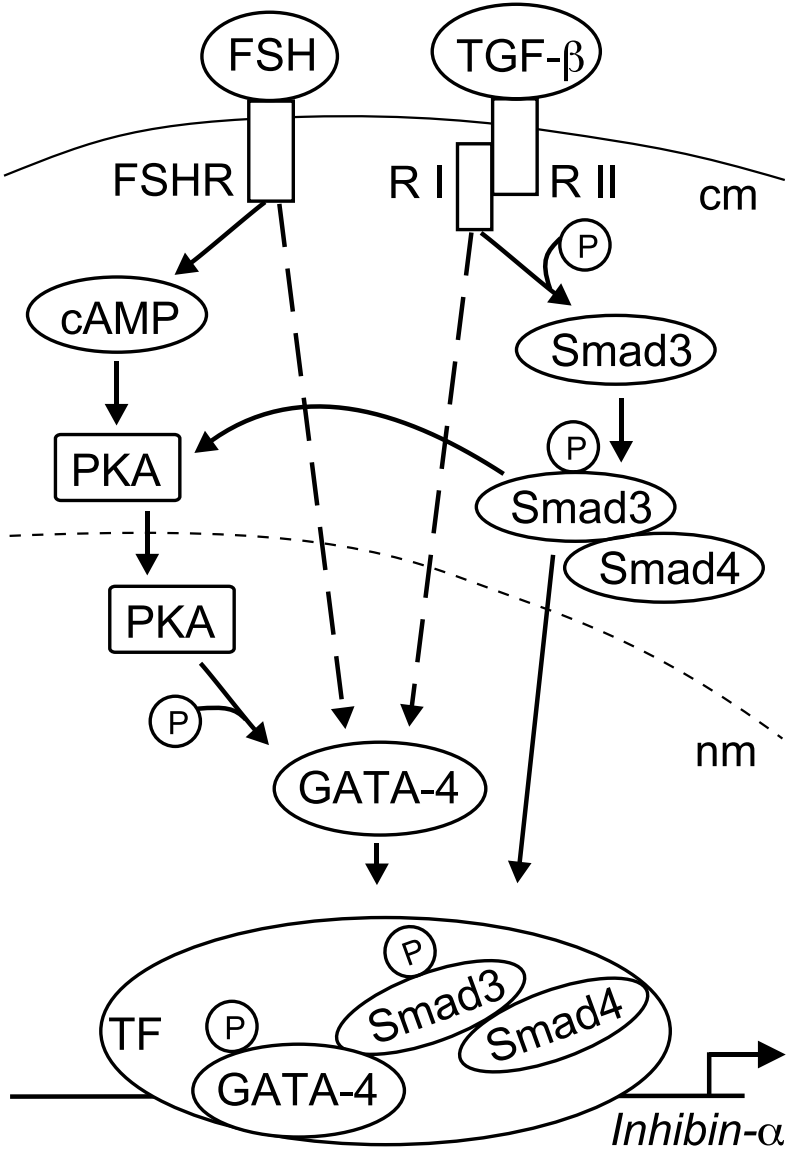

Figure 6 A schematic illustration of the signalling cascades employing GATA-4 in order to activate inhibin- $\alpha$ in granulosa cells. See discussion in text for details. In brief, PKA phosphorylates GATA-4; both FSH and TGF- $\beta$, upregulate GATA-4 expression by as yet unknown mechanisms; and Smad3 binds and cooperates with GATA-4. TGF- $\beta$ activates PKA by Smad3:Smad4 complex. cm: cellular membrane; $\mathrm{nm}$ : nuclear membrane; R I or R II: TGF- $\beta$ type I or type II receptor; $\mathrm{P}$ : phosphorylation; TF: large transcriptional coactivator protein, such as CREB-binding protein (CBP).

production in granulosa cells (Kaivo-Oja et al. 2003, Roh et al. 2003, Mazerbourg et al. 2004). Thus, the interplay of these more physiological ligands with GATA-4 will be the subject of further studies on signalling in the oocyte-granulosa cell axis.

We have recently highlighted the role of GATA-4 in adrenocortical cell proliferation (Kiiveri et al. 1999, 2002, Bielinska et al. 2003). In mice, high gonadotrophin levels are associated with formation of sex steroidproducing adrenocortical adenomas and abnormal GATA-4 expression (Bielinska et al. 2003, 2005). The same phenotype was seen in inhibin- $\alpha$-null mice, depending on the high luteinizing hormone level (Matzuk et al. 1992, Beuschlein et al. 2003, Looyenga et al. 2004). In addition, TGF- $\beta$-Smad3 signalling was recently linked to GATA-4 upregulation in the adrenals (Looyenga et al. 2004). We propose that GATA-4 and Smad3 are key factors in a transcriptional module orchestrating inhibin- $\alpha$ activation in granulosa cells (Fig. 6). Given that gonadotrophin- and TGF- $\beta$-induced signalling activates both inhibin- $\alpha$ and GATA-4, GATA-4 may serve as a link between endocrine and paracrine gene regulation in granulosa cells.

\section{Acknowledgements}

We thank Ilpo Huhtaniemi for providing the KK-1 cell line; Peter ten Dijke, Aaron Hsueh, Aristidis Moustakas and Stuart Orkin for providing plasmid constructs; Taru Jokinen for skilful technical assistance; and Ralf Butzow and Ilkka Ketola for methodological assistance and advice.

\section{Funding}

This work was financially supported by the Finnish Pediatric Research Foundation, the Sigrid Jusélius Foundation, the Emil Aaltonen Foundation, the Jalmari and Rauha Ahokas Foundation, the Finnish Cultural Foundation, NIH DK52574, and AHA 0455623Z. There is no conflict of interest that would prejudice the impartiality of this work.

\section{References}

Anttonen M, Ketola I, Parviainen H, Pusa AK \& Heikinheimo M 2003 FOG-2 and GATA-4 Are coexpressed in the mouse ovary and can modulate müllerian-inhibiting substance expression. Biology of Reproduction 68 1333-1340.

Anttonen M, Unkila-Kallio L, Leminen A, Butzow R \& Heikinheimo M 2005 High GATA-4 expression associates with aggressive behavior, whereas low anti-Müllerian hormone expression associates with growth potential of ovarian granulosa cell tumors. Fournal of Clinical Endocrinology and Metabolism 90 6529-6535.

Arceci RJ, King AA, Simon MC, Orkin SH \& Wilson DB 1993 Mouse GATA-4: a retinoic acid-inducible GATA-binding transcription factor expressed in endodermally derived tissues and heart. Molecular and Cellular Biology 13 2235-2246.

Ariizumi T, Kinoshita M, Yokota C, Takano K, Fukuda K, Moriyama N, Malacinski GM \& Asashima M 2003 Amphibian in vitro heart induction: a simple and reliable model for the study of vertebrate cardiac development. International Fournal of Developmental Biology 47 405-410.

Beuschlein F, Looyenga BD, Bleasdale SE, Mutch C, Bavers DL, Parlow AF, Nilson JH \& Hammer GD 2003 Activin induces $\mathrm{x}$-zone apoptosis that inhibits luteinizing hormone-dependent adrenocortical tumor formation in inhibin-deficient mice. Molecular and Cellular Biology 23 3951-3964.

Bielinska M, Parviainen H, Porter-Tinge SB, Kiiveri S, Genova E, Rahman N, Huhtaniemi IT, Muglia LJ, Heikinheimo M \& Wilson DB 2003 Mouse strain susceptibility to gonadectomyinduced adrenocortical tumor formation correlates with the 
expression of GATA-4 and luteinizing hormone receptor. Endocrinology 144 4123-4133.

Bielinska M, Genova E, Boime I, Parviainen H, Kiiveri S, Leppaluoto J, Rahman N, Heikinheimo M \& Wilson DB 2005 Gonadotropin-induced adrenocortical neoplasia in NU/J nude mice. Endocrinology 146 3975-3984.

Blokzijl A, ten Dijke P \& Ibanez CF 2002 Physical and functional interaction between GATA-3 and Smad3 allows TGF-beta regulation of GATA target genes. Current Biology 12 35-45.

Bristol SK \& Woodruff TK 2004 Follicle-restricted compartmentalization of transforming growth factor beta superfamily ligands in the feline ovary. Biology of Reproduction $70846-859$.

Brown CO 3rd, Chi X, Garcia-Gras E, Shirai M, Feng XH \& Schwartz RJ 2004 The cardiac determination factor, Nkx2-5, is activated by mutual cofactors GATA- 4 and Smadl/4 via a novel upstream enhancer. Fournal of Biological Chemistry 279 10659-10669.

Chang AN, Cantor AB, Fujiwara Y, Lodish MB, Droho S, Crispino JD \& Orkin SH 2002 GATA-factor dependence of the multitype zinc-finger protein FOG-1 for its essential role in megakaryopoiesis. PNAS 99 9237-9242.

Dennler S, Itoh S, Vivien D, ten Dijke P, Huet S \& Gauthier JM 1998 Direct binding of Smad3 and Smad4 to critical TGF beta-inducible elements in the promoter of human plasminogen activator inhibitor-type 1 gene. EMBO fournal 17 3091-3100.

Drummond A, Dyson M, Thean E, Groome N, Robertson D \& Findlay J 2000 Temporal and hormonal regulation of inhibin protein and subunit mRNA expression by post-natal and immature rat ovaries. Fournal of Endocrinology 166 339-354.

Dunn NR, Koonce CH, Anderson DC, Islam A, Bikoff EK \& Robertson EJ 2005 Mice exclusively expressing the short isoform of Smad2 develop normally and are viable and fertile. Genes and Development 19 152-163.

Feng ZM, Wu AZ, Zhang Z \& Chen CL 2000 GATA-1 and GATA-4 transactivate inhibin/activin beta-B-subunit gene transcription in testicular cells. Molecular Endocrinology 14 1820-1835.

Findlay JK, Drummond AE, Dyson M, Baillie AJ, Robertson DM \& Ethier JF 2001 Production and actions of inhibin and activin during folliculogenesis in the rat. Molecular and Cellular Endocrinology $180139-144$.

Hanafusa H, Ninomiya-Tsuji J, Masuyama N, Nishita M, Fujisawa J, Shibuya H, Matsumoto K \& Nishida E 1999 Involvement of the p38 mitogen-activated protein kinase pathway in transforming growth factor-beta-induced gene expression. Fournal of Biological Chemistry 274 27161-27167.

Heikinheimo M, Ermolaeva M, Bielinska M, Rahman NA, Narita N, Huhtaniemi IT, Tapanainen JS \& Wilson DB 1997 Expression and hormonal regulation of transcription factors GATA-4 and GATA-6 in the mouse ovary. Endocrinology 138 3505-3514.

Kaivo-Oja N, Bondestam J, Kamarainen M, Koskimies J, Vitt U, Cranfield M, Vuojolainen K, Kallio JP, Olkkonen VM, Hayashi M et al. 2003 Growth differentiation factor-9 induces Smad2 activation and inhibin $\mathrm{B}$ production in cultured human granulosa-luteal cells. Fournal of Clinical Endocrinology and Metabolism $88755-762$.

Kananen K, Markkula M, Rainio E, Su JG, Hsueh AJ \& Huhtaniemi IT 1995 Gonadal tumorigenesis in transgenic mice bearing the mouse inhibin alpha-subunit promoter/simian virus $\mathrm{T}$-antigen fusion gene: characterization of ovarian tumors and establishment of gonadotropin-responsive granulosa cell lines. Molecular Endocrinology 9 616-627.

Kang Y, Chen CR \& Massague J 2003 A self-enabling TGFbeta response coupled to stress signaling: Smad engages stress response factor ATF3 for Id1 repression in epithelial cells. Molecular Cell 11 915-926.
Kawabata M, Inoue H, Hanyu A, Imamura T \& Miyazono K 1998 Smad proteins exist as monomers in vivo and undergo homo- and hetero-oligomerization upon activation by serine/threonine kinase receptors. EMBO Fournal 17 4056-4065.

Ketola I, Rahman N, Toppari J, Bielinska M, Porter-Tinge SB, Tapanainen JS, Huhtaniemi IT, Wilson DB \& Heikinheimo M 1999 Expression and regulation of transcription factors GATA-4 and GATA-6 in developing mouse testis. Endocrinology $1401470-1480$.

Kiiveri S, Siltanen S, Rahman N, Bielinska M, Lehto VP, Huhtaniemi IT, Muglia LJ, Wilson DB \& Heikinheimo M 1999 Reciprocal changes in the expression of transcription factors GATA-4 and GATA-6 accompany adrenocortical tumorigenesis in mice and humans. Molecular Medicine 5 490-501.

Kiiveri S, Liu J, Westerholm-Ormio M, Narita N, Wilson DB, Voutilainen R \& Heikinheimo M 2002 Transcription factors GATA-4 and GATA-6 during mouse and human adrenocortical development. Endocrine Research 28 647-650.

Kuo CT, Morrisey EE, Anandappa R, Sigrist K, Lu MM, Parmacek MS, Soudais C \& Leiden JM 1997 GATA4 transcription factor is required for ventral morphogenesis and heart tube formation. Genes and Development 11 1048-1060.

Laitinen MP, Anttonen M, Ketola I, Wilson DB, Ritvos O, Butzow R \& Heikinheimo M 2000 Transcription factors GATA-4 and GATA- 6 and a GATA family cofactor, FOG-2, are expressed in human ovary and sex cord-derived ovarian tumors. Fournal of Clinical Endocrinology and Metabolism 85 3476-3483.

Lanuza GM, Groome NP, Baranao JL \& Campo S 1999 Dimeric inhibin $\mathrm{A}$ and $\mathrm{B}$ production are differentially regulated by hormones and local factors in rat granulosa cells. Endocrinology $1402549-2554$

Li TS, Hayashi M, Ito H, Furutani A, Murata T, Matsuzaki M \& Hamano K 2005 Regeneration of infarcted myocardium by intramyocardial implantation of ex vivo transforming growth factor-beta-preprogrammed bone marrow stem cells. Circulation $1112438-2445$.

Looyenga BD, Beuschlein F, Nilson JH \& Hammer GD 2004 Mechanistic roles of inhibin as a tumor suppressor in the adrenal cortex. Endocrine Research 30 585-586.

Martelin E, Palvimo JJ, Lapatto R \& Raivio KO 2000 Nuclear factor $\mathrm{Y}$ activates the human xanthine oxidoreductase gene promoter. FEBS Letter 480 84-88.

Massague J, Blain SW \& Lo RS 2000 TGFbeta signaling in growth control, cancer, and heritable disorders. Cell 103 295-309.

Matzuk MM, Finegold MJ, Su JG, Hsueh AJ \& Bradley A 1992 Alpha-inhibin is a tumour-suppressor gene with gonadal specificity in mice. Nature 360 313-319.

Mazerbourg S, Klein C, Roh J, Kaivo-Oja N, Mottershead DG, Korchynskyi O, Ritvos O \& Hsueh AJ 2004 Growth differentiation factor-9 signaling is mediated by the type I receptor, activin receptor-like kinase 5. Molecular Endocrinology 18 653-665.

Molkentin JD, Lin Q, Duncan SA \& Olson EN 1997 Requirement of the transcription factor GATA4 for heart tube formation and ventral morphogenesis. Genes and Development 11 1061-1072.

Morrisey EE, Ip HS, Tang Z \& Parmacek MS 1997 GATA-4 activates transcription via two novel domains that are conserved within the GATA-4/5/6 subfamily. Fournal of Biological Chemistry $2728515-8524$.

Nakao A, Imamura T, Souchelnytskyi S, Kawabata M, Ishisaki A, Oeda E, Tamaki K, Hanai J, Heldin CH, Miyazono K et al. 1997 TGF-beta receptor-mediated signalling through Smad2, Smad3 and Smad4. EMBO Fournal 16 5353-5362.

Pikkarainen S, Tokola H, Majalahti-Palviainen T, Kerkela R, Hautala N, Bhalla SS, Charron F, Nemer M, Vuolteenaho O \& Ruskoaho H 2003 GATA-4 is a nuclear mediator of mechanical stretch-activated hypertrophic program. Fournal of Biological Chemistry 278 23807-23816. 
Rahman NA, Kiiveri S, Rivero-Muller A, Levallet J, Vierre S, Kero J, Wilson DB, Heikinheimo M \& Huhtaniemi I 2004 Adrenocortical tumorigenesis in transgenic mice expressing the inhibin alpha-subunit promoter/simian virus $40 \mathrm{~T}$-antigen transgene: relationship between ectopic expression of luteinizing hormone receptor and transcription factor GATA-4. Molecular Endocrinology 18 2553-2569.

Robert NM, Tremblay JJ \& Viger RS 2002 Friend of GATA (FOG)-1 and FOG-2 differentially repress the GATA-dependent activity of multiple gonadal promoters. Endocrinology 143 3963-3973.

Roh JS, Bondestam J, Mazerbourg S, Kaivo-Oja N, Groome N, Ritvos O \& Hsueh AJ 2003 Growth differentiation factor-9 stimulates inhibin production and activates Smad2 in cultured rat granulosa cells. Endocrinology 144 172-178.

Shi Y, Wang YF, Jayaraman L, Yang H, Massague J \& Pavletich NP 1998 Crystal structure of a Smad MHl domain bound to DNA: insights on DNA binding in TGF-beta signaling. Cell 94 585-594.

Svensson EC, Huggins GS, Dardik FB, Polk CE \& Leiden JM 2000 A functionally conserved N-terminal domain of the friend of GATA-2 (FOG-2) protein represses GATA4-dependent transcription. Fournal of Biological Chemistry 275 20762-20769.

Tevosian SG, Deconinck AE, Cantor AB, Rieff HI, Fujiwara Y, Corfas G \& Orkin SH 1999 FOG-2: a novel GATA-family cofactor related to multitype zinc-finger proteins Friend of GATA-1 and U-shaped. PNAS 96 950-955.

Tevosian SG, Deconinck AE, Tanaka M, Schinke M, Litovsky SH, Izumo S, Fujiwara Y \& Orkin SH 2000 FOG-2, a cofactor for GATA transcription factors, is essential for heart morphogenesis and development of coronary vessels from epicardium. Cell $101729-739$.

Tevosian SG, Albrecht KH, Crispino JD, Fujiwara Y, Eicher EM \& Orkin SH 2002 Gonadal differentiation, sex determination and normal Sry expression in mice require direct interaction between transcription partners GATA4 and FOG2. Development $1294627-4634$.

Tomic D, Miller KP, Kenny HA, Woodruff TK, Hoyer P \& Flaws JA 2004 Ovarian follicle development requires Smad3. Molecular Endocrinology 18 2224-2240.
Tremblay JJ \& Viger RS 1999 Transcription factor GATA-4 enhances Müllerian inhibiting substance gene transcription through a direct interaction with the nuclear receptor SF-1. Molecular Endocrinology 13 1388-1401.

Tremblay JJ \& Viger RS 2001 GATA factors differentially activate multiple gonadal promoters through conserved GATA regulatory elements. Endocrinology 142 977-986.

Tremblay JJ \& Viger RS 2003a Novel roles for GATA transcription factors in the regulation of steroidogenesis. Fournal of Steroid Biochemistry and Molecular Biology 85 291-298.

Tremblay JJ \& Viger RS $2003 b$ Transcription factor GATA-4 is activated by phosphorylation of serine 261 via the cAMP/protein kinase A signaling pathway in gonadal cells. Fournal of Biological Chemistry 278 22128-22135.

Tsang AP, Visvader JE, Turner CA, Fujiwara Y, Yu C, Weiss MJ, Crossley M \& Orkin SH 1997 FOG, a multitype zinc finger protein, acts as a cofactor for transcription factor GATA-1 in erythroid and megakaryocytic differentiation. Cell 90 109-119.

Tsang AP, Fujiwara Y, Hom DB \& Orkin SH 1998 Failure of megakaryopoiesis and arrested erythropoiesis in mice lacking the GATA-1 transcriptional cofactor FOG. Genes and Development $121176-1188$.

Vaskivuo TE, Anttonen M, Herva R, Billig H, Dorland M, te Velde ER, Stenback F, Heikinheimo M \& Tapanainen JS 2001 Survival of human ovarian follicles from fetal to adult life: apoptosis, apoptosis-related proteins, and transcription factor GATA-4. Fournal of Clinical Endocrinology and Metabolism 86 3421-3429.

Xu J, Oakley J \& McGee EA 2002 Stage-specific expression of Smad2 and Smad3 during folliculogenesis. Biology of Reproduction 66 1571-1578.

Zhang L, Duan CJ, Binkley C, Li G, Uhler MD, Logsdon CD \& Simeone DM 2004 A transforming growth factor beta-induced Smad3/Smad4 complex directly activates protein kinase A. Molecular and Cellular Biology 24 2169-2180.

Received in final form 18 February 2006 Accepted 27 February 2006 